\title{
GUS DUR DALAM KEBERAGAMAN PENDIDIKAN ISLAM
}

\author{
Nur Solikhin \\ Universitas Islam Negeri Sunan Kalijaga Yogyakarta \\ nursholikhin14@gmail.com
}

\begin{abstract}
Abstrak
Persepsi publik seringkali menganggap bahwa pendidikan Islam hanya fokus di lembaga formal. Apabila persepsi itu terus langgeng, maka pendidikan Islam akan sulit untuk menjawab tantangan modernitas. Artikel ini memaparkan bagaimana cara kerja pikiran Gus Dur dalam pemikiran pendidikan Islam. Teori persepsi diri digunakan untuk melihat proses pembentukan konsep diri, harga diri dan presentasi diri Gus Dur. Dengan pendekatan metode kualitatif dan teknik pengumpulan data dokumentasi, studi ini menemukan bahwa pada bagian konsep diri, proses pembentukan diri Gus Dur dilakukan melalui pengalaman, pengetahuan, tingkah laku, penilaian orang lain, perhatian, minat dan suasana hati. Hal yang membentuk konsep diri Gus Dur, yaitu orang, buku dan situasi. Pada bagian harga diri, terdapat nilai-nilai yang melekat pada diri Gus Dur dan nilai yang diperjuangkannya. Pemikiran pendidikan keislaman Gus Dur tidak secara tiba-tiba, tapi melalui pembentukan konsep diri dan harga diri. Gus Dur mempresentasikan pemikirannya tentang pendidikan Islam untuk menjawab tantangan modernitas.
\end{abstract}

Kata Kunci: Gus Dur, Persepsi Diri, Pendidikan Islam

\section{Abstract}

The public perception often perceives that Islamic education has only focused on formal institutions. If this perception continues, Islamic education will find it difficult to answer the challenges of modernity. This article describes how Gus Dur's thoughts evolve around Islamic education discourses. Self-perception theory is used to see the process of forming self-concept, self-esteem and selfpresentation of Gus Dur. With a qualitative method approach and a documentation data technique, this study found that in the self-concept section, Gus Dur's self-formation process was carried out through experience, knowledge, behavior, other people's judgments, attention, interests and self-mood. Gus Dur's

Copyright @ Jurnal Tashwirul Afkar Vol. 38, No. 01, Tahun 2020. 
self-concept was shaped by people, books and socio-political situations. On the part of self-esteem, there are some inherent values of Gus Dur that he fought for in his entire life. The thought of Gus Dur about the issue of Islamic education were not sudden, but through the formation of self-concept and self-esteem. Gus Dur presented his thoughts on Islamic education to answer the challenges of modernity.

Keywords: Gus Dur, Self Perception, Islamic Education 


\section{Pendahuluan}

Persepsi yang seringkali muncul tentang pendidikan Islam, maka akan tertuju pada lembaga formal yang berupa madrasah atau sekolah agama. Persepsi itu yang membuat melupakan kenyataan bahwa pendidikan Islam banyak dilaksanakan di masyarakat, namun kurang mendapatkan perhatian, semisal forum shalawat serta forum-forum lainnya yang berkembang di masyarakat. Jika Pendidikan Islam lebih banyak dipersepsikan pada lembaga formal, maka pendidikan Islam akan kesulitan menghadapi tantangan modernisasi atau menjawab tantangan problematika masyarakat.

Ruang lingkup Pendidikan Islam selalu menyesuaikan perkembangan dan perubahan tuntutan zaman dan perkembangan ilmu dan teknologi. Sudah semestinya pendidikan khususnya pendidikan Islam bisa menghadapi tantangan modernisasi dan tantangan yang ada di masyarakat. Karena secara teoritis, ruang lingkup Pendidikan Islam mencakup kegiatankegiatan kependidikan yang dilakukan secara konsisten dan berkesinambungan dalam bidang atau ruang lingkup hidup manusia. Ruang lingkup itu bisa berupa keagamaan, keluarga, ekonomi, kemasyarakatan, politik, seni budaya dan ilmu pengetahuan. Pendidikan Islam memang sudah semestinya berbicara dalam ruang lingkup kehidupan manusia tersebut. ${ }^{1}$

Pendidikan Islam yang hanya mengutamakan ajaran-ajaran formal tanpa memerhatikan kenyataan sosial, bisa jadi akan menimbulkan cara beragama yang eksklusif. Cara beragama yang eksklusif akan membuat pemeluknya menutup diri dari perbedaan. Perbedaan cara mengekspresikan keberagamaan, apalagi perbedaan keyakinan akan dianggap permasalahan krusial baginya. Sikap semacam itu akan mengancam keberagaman yang dibangun oleh para pendahulu. Bhinneka Tunggal Ika akan hanya menjadi simbol belaka apabila cara beragama yang eksklusif semakin merebak.

Penelitian Puslitbang Kehidupan Keagamaan Badan Libang dan Diklat Kementerian Agama (Kemenag) RI menyatakan, eksklusivisme beragama seseorang dipengaruhi atau ditentukan oleh pemahaman keberagamaannya. Semakin tinggi pemahaman keagamaan seseorang ternyata semakin kurang eksklusif beragamanya (semakin rendah skor eksklusivismenya). Begitu

1Rosmiaty Aziz, Ilmu Pendidikan Islam, (Yogyakarta: Sibuku, 2019), h. 12. 
juga sebaliknya, semakin kurang pemahaman keagamaan seseorang maka akan semakin eksklusif orang tersebut. ${ }^{2}$

Eksklusivitas cara beragama erat kaitannya dengan cara seseorang memperoleh pendidikan yang literal dalam memahami teks-teks Islam (tekstualis). ${ }^{3}$ Ketika para pendidik mempunyai wawasan agama yang sempit, kemungkinan akan terjadi eksklusivisme. Sebagaimana penelitian yang dihasilkan oleh Puslitbang Kemenag seperti yang telah dijelaskan sebelumnya, bahwa lingkungan tempat tinggal memengaruhi keberagamaan seseorang. Semakin heterogen atau semakin banyak keluarga yang berbeda agama di lingkungan tempat tinggal seseorang, maka semakin mudah skor keberagamaannya, atau katakanlah lebih moderat. Begitu juga sebaliknya, semakin homogen lingkungan agama seseorang, maka semakin kuat skor keberagamaannya.

Gus Dur juga kurang sepakat dengan adanya eksklusivisme. Baginya, Islam memiliki cara hidupnya sendiri, yang tidak perlu dipertahankan dengan kekerasan, karena cukup dikembangkan dalam bentuk budaya. Inilah yang terjadi, seperti adanya Musabaqah Tilwatul Qur'an (MTQ), penerbitan-penerbitan Islam yang berjumlah sangat banyak dan berbagai manifestasi ke-Islaman lain. Bahkan sekarang, wajah "kesenian Islam" sudah menonjol demikian rupa sehingga layar televisi pun menampung sekian banyak dari berbagai wajah seni Islam. Karena itu, bagi Gus Dur, Islam tidak perlu dipertahankan dari ancaman siapapun karena memiliki dinamika tersendiri. Sebagai responsi atas "tekanan-tekanan" modernisasi, terutama dari "proses-pembarat-an" yang terjadi, kaum muslimin di negeri ini dapat mengambil atau menolak pilihan-pilihan mereka sendiri dari proses tersebut, mana yang mereka anut dan mana yang mereka buang. Karena itu, hasilnya juga akan berbeda-beda dari satu orang ke orang lain dan dari satu kelompok ke kelompok lain. Penerimaan beragam atas proses itu membuat variasi sangat tinggi dari responsi tersebut, yang sesuai dengan firman Allah: "dan Ku-jadikan kalian berbangsa-bangsa dan bersuku-suku bangsa untuk dapat saling mengenal (wa ja'alnakum syu'uban wa waqabaila li ta'arafu)" (QS. Al-Hujarat (49):13). Bagi Gus Dur, ayat tersebut jelas

${ }^{2}$ Ahsanul Khalikin dan Zirwansyah, Pandangan Pemuka Agama Tentang Ekslusivisme Beragama di Indonesia, (Jakarta: Puslitbang Kehidupan Keagamaan Badan Litbang dan Diklat Kementerian Agama RI, 2013), h. 137.

${ }^{3}$ Muhammad Yusup, "Eksklusivisme Beragama Jaringan Sekolah Islam Terpadu (JSIT) Yogyakarta”, Jurnal Religi vol. 13, No. 1, 2017, h. 88. 
memerintahkan adanya ke-kbinekaan dan melarang eksklusivisme dari kalangan kaum muslimin manapun. ${ }^{4}$

Keberagaman dalam pendidikan Islam harus benar-benar diperhatikan. Sikap mengabaikan keberagaman ini menurut Gus Dur, sama dengan sikap burung onta yang menyembunyikan kepalanya di bawah timbunan pasir tanpa menyadari badannya masih tampak. Jalan terbaik menurutnya adalah, membiarkan keanekaragaman sangat tinggi dalam pendidikan Islam dan membiarkan perkembangan waktu dan tempat yang akan menentukan. ${ }^{5}$

Pendidikan Islam bagi Gus Dur sangat beragam karena adanya perkembangan zaman. Pendidikan Islam bukan hanya terbatas oleh tembok dan bangku sekolah, melainkan banyak berkembang di masyarakat. Tulisan ini akan membahas lebih dalam tentang pemikiran Gus Dur tentang pendidikan Islam.

Menggunakan pendekatan psikologi kognitif, yaitu tentang persepsi diri, tulisan ini akan membedah apa saja yang memengaruhi konsep diri keislaman Gus Dur sehingga mempunyai corak pemikiran pendidikan Islam tersendiri. Memang porsi Gus Dur menulis tentang dunia pendidikan sangat sedikit, namun dari konsep diri keislamannya akan terungkap pijakan Gus Dur yang menghasilkan pemikiran tentang pendidikan dan keislaman.

Gus Dur memang bukan seorang spesifik ahli dalam bidang pendidikan seperti halnya Ki Hajar Dewantara, yang menuliskan tentang pendidikan hingga membuat sekolah. Gus Dur berbicara banyak hal, mulai dari keislaman, politik, ekonomi, gerakan sosial, pendidikan dan lain sebagainya. Walaupun ia pernah menjadi seorang guru, namun, kiprahnya tidak seperti Ki Hajar Dewantara yang mengembangkan pendidikan sesuai dengan pikirannya. Waktunya banyak dihabiskan sebagai aktivis sosial, ketua PBNU, pernah juga menjadi Presiden Republik Indonesia serta karir lainnya.

Pada tulisan ini, penulis lebih pada mendalami proses persepsi Gus Dur, dimulai dari pembentukan intelektualismenya hingga pada representasi pemikiran Gus Dur terkait dengan Pendidikan Islam. Tulisan ini bukan hanya sebatas mendalami gagasan Gus Dur, melainkan menelusuri proses pembentukan persepsi Gus Dur yang dipengaruhi tiga hal yaitu orang, buku dan situasi.

${ }^{4}$ Abdurrahman Wahid, NU dan Terorisme Bekedok Islam dalam Islamku Islam Anda dan Islam Kita (Jakarta, The Wahid Institute, 2006), h. 304

${ }^{5}$ Abdurrahman Wahid, Pendidikan Islam Harus Beragam, dalam Islamku Islam Anda dan Islam Kita (Jakarta, The Wahid Institute, 2006), h. 227. 


\section{Persepsi Diri Gus Dur}

Gus Dur dikenal sebagai sebagai seorang humanis, dalam artian yang sebenar-benarnya. Gus Dur selalu membela masyarakat yang lemah, tertindas, minoritas. ${ }^{6}$ Ada berbagai macam hal yang memengaruhinya, mengapa Gus Dur mempunyai perspektif keberpihakannya terhadap orang lemah atau sering dikenal mustad'afin. Gus Dur sebagai orang yang sederhana dan pengaruh buku-buku yang dibaca, akan memengaruhi sikapnya membela orang lemah.

Begitu juga dalam pemikiran lainnya, Gus Dur banyak dipengaruhi oleh berbagai macam stimulus, misalnya situasi, buku yang ia baca, budaya, orang yang ia temui, pendidikan dan lain sebagainya. Pengalamanpengalaman yang dimilikinya akan membentuk konsep diri Gus Dur yang memiliki pemikiran tentang pribumisasi Islam, ia yang memiliki pemikiran kosmopolitanisme dan univeraslisme Islam. Gus Dur yang memiliki sebuah gagasan pendidikan Islam yang dituangkan dalam sebuah tulisan "Pendidikan Islam Harus Beragam" dan tulisan-tulisan lainnya tentang wacana keislaman, bisa dilacak, bagaimana proses Gus Dur menghasilkan pemikiran yang terbuka dan progresif.

Setiap orang, termasuk juga Gus Dur telah melakukan proses interpretasi terhadap stimulus yang ia terima. Apabila yang dipersepsi diri sendiri maka akan dikenal adanya persepsi diri atau self-perception. Persepsi diri dapat dimaknai sebagai interpretasi seseorang terhadap diri sendiri. Ketika melakukan persepsi, seseorang melakukan proses kognitif. Proses kognitif akan melibatkan banyak aktivitas. Mulai dari penerimaan rangsangan (stimulus), memproses rangsang ke dalam sistem memori, dan menginterpretasi rangsang berdasarkan informasi yang telah disimpannya. ${ }^{7}$

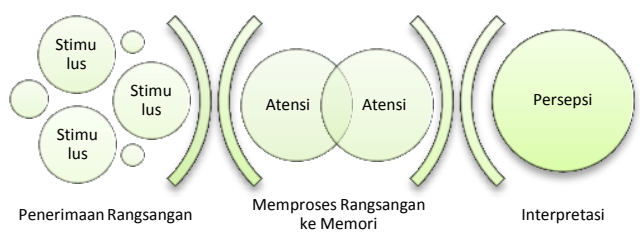

Bagan 1: Proses Kognitif Melakukan Persensi

${ }^{6}$ Franz Magnis Susesno, Gus Dur: Bangsa Mana di Dunia Mempunyai Presiden Seperti Kita! dalam Gila Gus Dur, (Yogyakarta: LKiS, 2010), h. 28.

${ }^{7}$ Suyanto, dkk. Pengantar Psikologi Sosial, (Surabaya: Pusat Penerbitan dan Percetakan Unair (AUP), 2012), h. 29. 
Persepsi dilakukan apabila dalam sistem memori terdapat informasi yang tepat senada dengan adanya stimulus tentang diri. Persepsi juga bisa saja salah apabila informasi tidak tepat dan disimpan atau memang informasi tersebut tidak berhubungan dengan stimulus. Setiap orang pasti menerima stimulus yang berbeda, dan mengalami proses atensi (perhatian) yang berbeda pula sehingga menghasilkan persepsi tentang dirinya berbeda dengan yang lainnya.

Damyanti (200) menggambarkan proses pembentukan persepsi pada skema berikut :

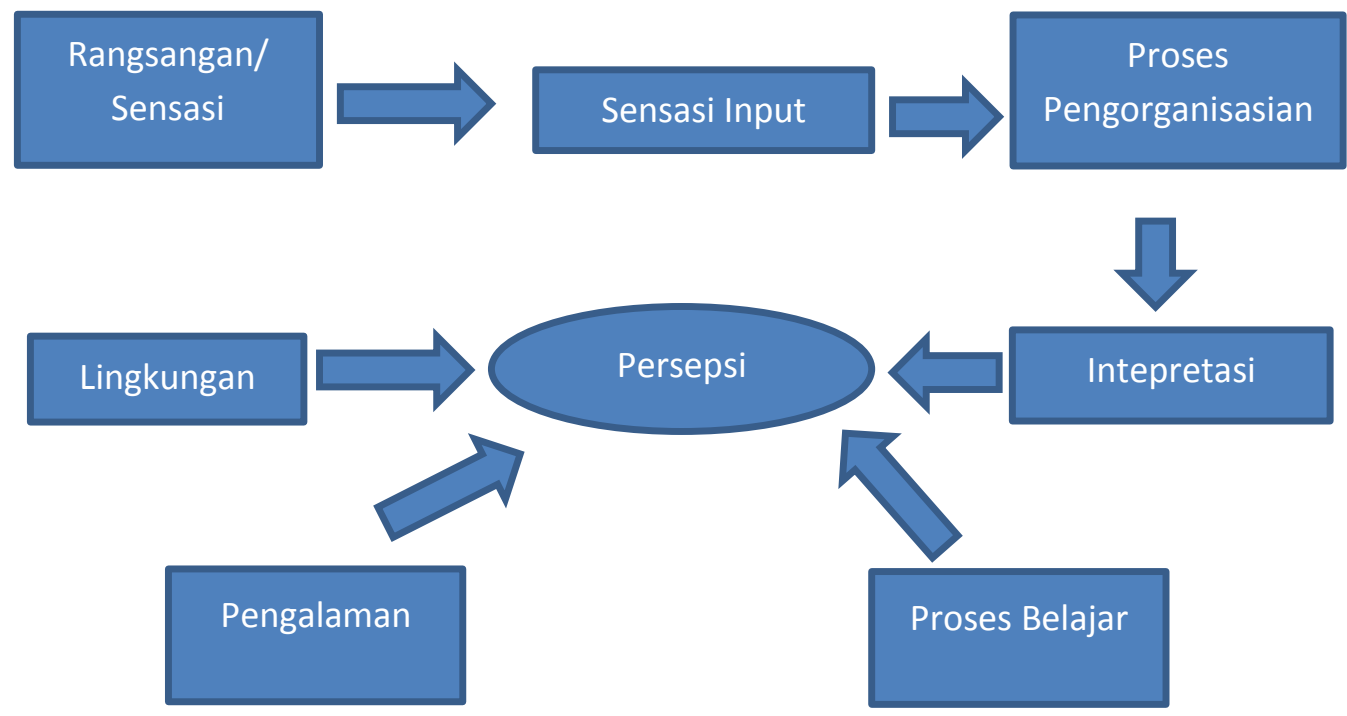

Bagan 2. Skema Pembentukan Persepsi

Proses pembentukan persepsi dimulai dari penerimaan rangsangan atau sensasi dari berbagai sumber yang diterima oleh panca indra. Persepsi diri mencakup tiga pembahasan. Pertama, konsep diri (slef-concept). Pada tahap ini, penulis akan memaparkan bagaimana proses pembentukan konsep diri Gus Dur sehingga memiliki pemikiran keislaman dan pendidikan. Kedua, harga diri (self esteem), dan ketiga adalah presentasi diri (self-prentation). Pada bagian ini, dijadikan dasar bagi seseorang untuk mengenali orang lain atau pihak lain. Atas dasar, setiap orang yang mengenali diri sendiri seperti apa gerangan dan pada akhirnya memengaruhinya dalam membawakan diri di lingkungan sekitar.

\section{Proses Pembentukan Konsep Diri Gus Dur}

Konsep diri seseorang pada hakikatnya dialah yang paling mengetahui. Dalam konteks Gus Dur, dialah yang paling mengetahui konsep dirinya. Namun sejarah perjalanan hidup Gus Dur tidak hanya dikonsumsi oleh 
dirinya sendiri, artinya perjalanan hidup Gus Dur sudah banyak dituliskan, terutama Greg Barton yang menuliskan buku Biografi Gus Dur.

Dari sejarah perjalanan hidup yang dituliskan oleh banyak orang, setidaknya penulis bisa menganalisis bagaimana konsep diri Gus Dur. Konsep diri Gus Dur tidak terbentuk secara tiba-tiba semenjak lahir. Proses kehidupan yang menghasilkan pengalaman-pengalaman hidup, kemudian menjadi pijakan seseorang untuk berbuat atau menyikapi sesuatu.

Konsep diri (self-concept) merupakan kesadaran seseorang mengenai dirinya. Brigham (1991: 90) menjelaskan bahwa konsep diri sebagai ut assumtions about our personal qualities, organized by self-shemas". Definisi yang diberikan oleh Brigham dapat dipahami bahwa konsep diri merupakan asumsi-asumsi tentang kualitas personal seseorang yang diorganisasikan oleh skema diri. Asumsi merujuk pada pernyataan atau pengetahuan seseorang yang bersifat hipotetik, mengingat pernyataan dan pengetahuan merupakan sebagai interpretasi terhadap kualitas personal yang selalu berubah dari waktu ke waktu. Sedangkan skema dalam hal ini merupakan representasi mental kita yang menghubungkan suatu peristiwa dengan beliefs tertentu.

Konsep diri dalam pengertian lain dijelaskan sebagai pengetahuan tentang diri, yang memengaruhi cara seseorang mengolah informasi dan mengambil tindakan. Konsep diri tidak begitu tiba-tiba muncul, melainkan dipengaruhi oleh orang lain dalam proses interaksi sosial. Bagi Cooley (1964), melalui analogi cermin sebagai sarana bagi seseorang melihat dirinya, konsep diri seseorang diperoleh dari hasil penilaian atau evaluasi terhadap dirinya. Apa yang dipikirkan orang lain tentang kita, menjadi sumber informasi tentang siapa diri kita. Namun, penilaian orang tidak menjadi ukuran satu-satunya yang membentuk konsep diri. Ketika seseorang melakukan suatu hal hasil dari tindakan kita juga akan membentuk konsep diri. Misalnya, ketika Gus Dur melihat perpustakaan ayahnya yaitu KH. Wahid Hasyim terdapat banyak buku. Melalui lingkungan keluarganya, dengan dorongan juga dari ibunya, Gus Dur mulai mengenal dunia literasi. Ia suka membaca koleksi ayahnya. Melalui pengamatan terhadap hal-hal yang telah dilakukan dan lingkungan di sekitanya, ia menyadari apakah dirinya termasuk orang yang suka atau tidak untuk membaca buku. ${ }^{8}$

Vaughan \& Hogg (2002), menyatakan bahwa hasil dari tindakan seseorang mendorong untuk melakukan introspeksi dan persepsi diri. Introspeksi dilakukan ketika ia berusaha memahami dan menilai mengapa

${ }^{8}$ Greg Barton, Biografi Gus Dur, (Yogyakarta: Saufa, 2016), h. 46. 
ia melakukan tindakan tertentu. Sedangkan persepsi diri dilakukan ketika seseorang ketika mengatribusikan secara internal hasil yang diterimanya. Beaman, Kelntz, Diener, \& Svanum (1979) telah melakukan eksperimen dan hasilnya, tingkah laku seseorang dipengaruhi oleh pengetahuan atau kesadaran tentang siapa dirinya. Pengetahuan tentang diri seseorang ada banyak proses yang diterima dan melalui atensi. Dari atensi, seseorang kemudian memproses tentang persepsi yang dihasilkan oleh dirinya sendiri. Dari berbagai macam pendapat dari para ahli, setidaknya penulis menemukan bagaimana pembentukan konsep diri seseorang. Ada berbagai hal yang membentuk konsep diri seseorang, yaitu pengalaman, pengetahuan, tingkah laku, penilaian orang lain, perhatian, minat, dan suasana hati.

Begitu juga dengan Gus Dur, yang membentuk konsep dirinya ada berbagai macam hal. Stimulus yang diterima oleh Gus Dur pasti sangat banyak, mengingat semenjak kecil ia sudah ikut ayahnya ke Jakarta ketika menjadi Menteri Agama. Di sana Gus Dur juga bertemu dengan tokoh-tokoh nasional. Apalagi ketika Gus Dur menjadi Ketua Pengurus Besar Nahdlatul Ulama (PBNU), Ketua Forum Demokrasi (Fordem) ${ }^{9}$ dan menjadi Presiden, pasti pergolakan hidupnya berbeda dengan orang pada umumnya sehingga memikirkan yang menarik dan progresif.

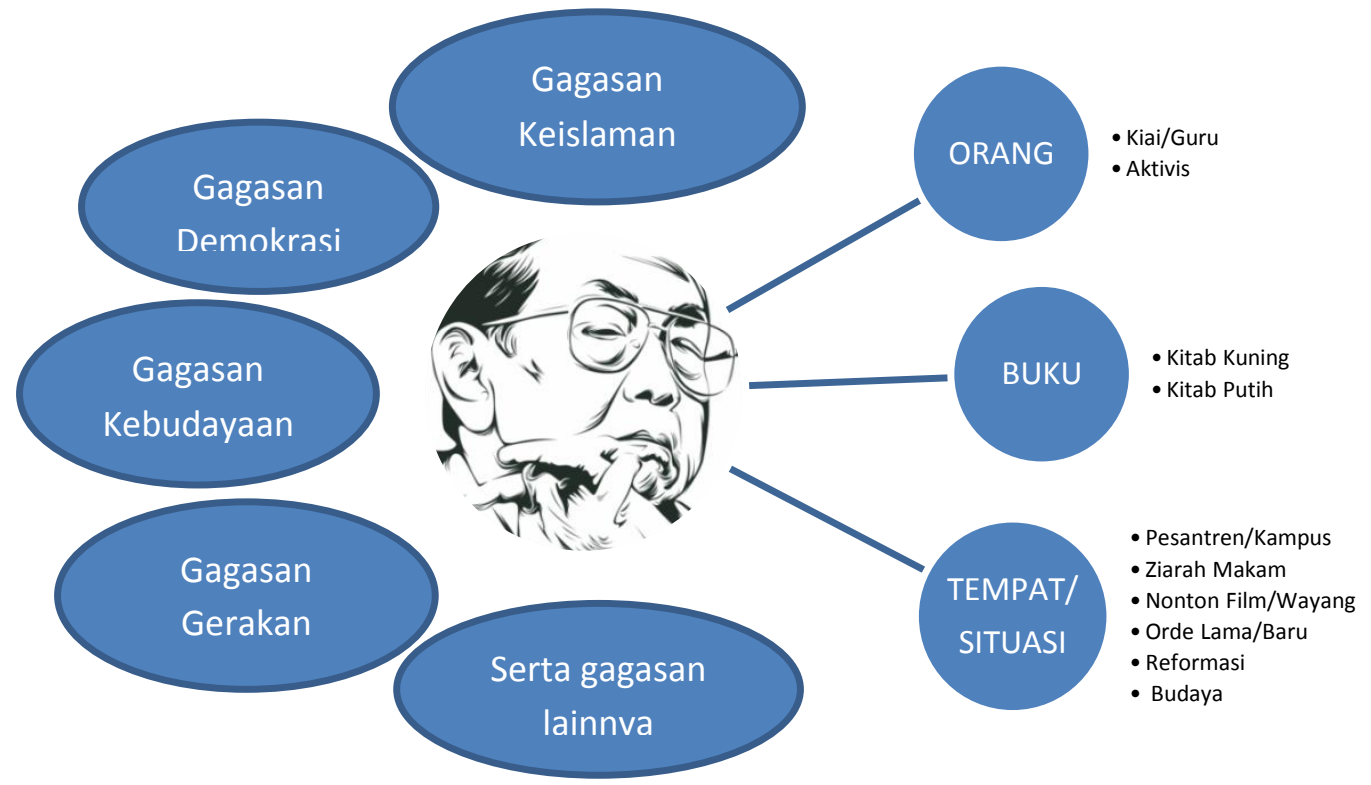

Bagan 3 : Proses Paembentukan Persepsi Diri

${ }^{9}$ Munawar Ahmad, Ijtihad Politik Gus Dur, Analisis Wacana Kritis (Yogyakarta: LKiS, 2010), h. 198.

Jurnal Tashwirul Afkar Vol. 38, No. 01, Tahun 2020. 
Gus Dur memiliki gagasan keislaman, demokrasi, kebudayaan, gerakan sosial serta gagasannya lainnya karena pengaruh dari stimulus yang selama ini ia terima dan diperhatikan. Pertemuan dengan para gurunya misalnya, sangat berpengaruh terhadap tindakan yang diambil olehnya. Begitu juga ketika situasi yang dialaminya, misalnya saat Orde Baru, ia banyak mengeluarkan kritik terhadap demokrasi yang dijalankan oleh pemerintah.

\section{Faktor-Faktor yang Memengaruhi Persepsi Diri Gus Dur}

Gus Dur pasti memiliki pengalaman tentang objek serta peristiwa yang berbeda dengan orang lain. Pengalaman tersebut mampu membentuk persepsi diri Gus Dur terhadap informasi yang diterima kemudian diinterpretasi. Rakhmat (2005) menyatakan bahwa persepsi adalah pengalaman tentang objek, peristiwa, atau hubungan-hubungan informasi dan menafsirkan pesan. Persepsi juga bisa dikatakan sebagai pemberian makna terhadap stimulus indrawi yang diterima.

Ada banyak faktor yang memengaruhi persepsi seseorang. Toha (2003), mengklasifikasikan faktor-faktor yang memengaruhi persepsi seseorang ada dua. Pertama, faktor internal yang terdiri dari perasaan, sikap dan karakteristik individu, prasangka, keinginan atau harapan, perhatian (fokus), proses belajar, keadaan fisik, gangguan kejiwaan, nilai dan kebutuhan juga minat, dan motivasi. Kedua, faktor eksternal, yang terdiri latar belakang keluarga, informasi yang diperoleh, pengetahuan dan kebutuhan sekitar, intensitas, ukuran, keberlawanan, pengulangan gerak, hal-hal baru dan familiar atau ketidak asingan suatu objek.

\section{Faktor Internal}

Faktor internal merupakan faktor yang diperoleh dari dalam diri seseorang dalam menciptakan dan menemukan sesuatu yang kemudian bermanfaat bagi orang lain. Melacak faktor internal pembentukan persepsi diri Gus Dur setidaknya ada 4 hal, usia, minat, proses belajar dan pekerjaan.

Pertama, usia merupakan umur individu yang dihitung semenjak ia dilahirkan sampai pada momentum-momentum tertentu, bahkan sampai ia wafat. Semakin cukup umur, kematangan dan kekuatan seseorang akan lebih matang dalam berpikir dan bekerja. Semakin tua umur seseorang semakin konstruktif dalam menggunakan pengetahuan yang diperolehnya (Nursalam, 2003). Begitu juga dengan Gus Dur, semakin tua umur Gus Dur maka akan semakin matang juga dalam bersikap dan bertindak. Dalam perjalanan hidupnya, ia mempunyai banyak pengetahuan, pengalaman dan persinggungan dengan banyak orang. Dari pengalaman termasuk informasi yang diterimanya, akan memengaruhi sikap dan tindakan Gus Dur. 
Gus Dur ketika menjadi ketua PBNU membela orang-orang yang dilemahkan oleh sistem, atau membela mereka yang mengalami kekerasan pastinya ada pengaruh dari pengalaman atau informasi yang ia peroleh, misalnya dari hasil buku bacaannya. Usia sangat memengaruhi tingkat pengetahuan seseorang. Misalnya, Gus Dur belum mempunyai perspektif soal kebudayaan yang kuat di masa kecilnya, karena ia belum mempunyai pengalaman langsung pergolakan antara kebudayaan dan agama di pondok pesantrennya di Magelang. ${ }^{10}$ Usia sangat memengaruhi tingkat pengetahuan dan pengalaman seseorang dan semakin cukup umur, tingkat kematangan dan kekuatan seseorang akan lebih matang dalam berpikir dan bekerja (Nursalam \& Pariani, 2001). Fase Gus Dur menjadi anak-anak, remaja, tua pastinya berpengaruh terhadap tingkat pengetahuan yang ia peroleh.

Kedua, minat Gus Dur semenjak kecil sudah terlihat, yaitu membaca buku. Ia mulai tertarik terhadap buku-buku ayahnya dan karena didorong ibunya untuk selalu membaca buku. Selain membaca buku, minatnya terhadap bermain bola dan nonton film sangat memengaruhi hidupnya, bahkan ia sampai tidak naik kelas.

Pada tahun 1954, Gus Dur berangkat ke Yogyakarta. Di kota tersebut minatnya membaca semakin tinggi, ia bahkan membaca buku-buku kiri. Minatnya menonton film pun semakin ia gemari. Selain minat-minat tersebut, Gus Dur juga minat untuk belajar bahasa Arab kepada KH. Ali Maksum. Pada tahun 1959, Gus Dur saat pindah ke Jombang dan belajar ke Kiai Wahab Chasbullah ia belajar dengan pendekatan sufistik. Minatnya terhadap ziarah ke makam-makam dengan jalan kaki. Di Jombang selain mengajar, Gus Dur mulai menulis di media massa, seperti halnya di Majalah Horison dan Budaya Jaya. Pada tahun 1960, minatnya terhadap belajar Islam bukan hanya khazanah Islam di pesantren, namun ia belajar Islam fundamentalis. Minatnya terhadap pendidikan juga tinggi, pada bagian pendidikan akan dibahas pada bagian setelahnya. Pada tahun 1964, saat kuliah di Al-Azhar, Kairo Mesir, minatnya menonton film masih berlanjut, bahkan ia banyak diskusi juga di kedai kopi.

Bacaannya Gus Dur juga mulai merambah ke khazanah keilamuan Eropa. Ia banyak membaca juga karya William Fulkner, Ernest Hemmingway, Edgar Alan Poe Andre Gilde, Kafka, Tolstoy, seperti puisi John Denne. Pada saat itu gairah intelektual gagasan Eropa sangat tinggi di Kairo. Minatnya terhadap membaca dan diskusi ia lanjutkan ketika kuliah di

${ }^{10}$ Abdurrahman Wahid, Melawan Melalui Lelucon (Jakarta: Pusat Data dan Analisa TEMPO, 2000), h. 36.

Jurnal Tashwirul Afkar Vol. 38, No. 01, Tahun 2020. 
Bagdad. Di sana ia juga belajar bahasa Prancis, juga belajar tradisi-tradisi Yahudisme dengan Ramin teman kerjanya di kantor Pedagang kain.

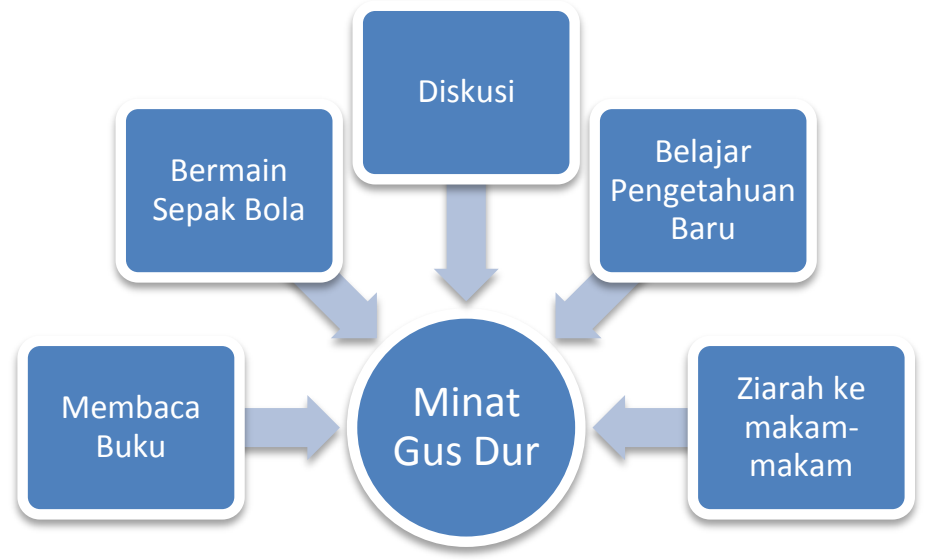

Bagan 4: Minat Gus Dur

Ketiga, proses belajar (pendidikan). Proses belajarnya Gus Dur dimulai semenjak ia usia dini. Bahkan pada usia lima tahun, ia sudah lancar membaca Al-Qur'an. Ia belajar membaca Al-Qur'an dengan kakeknya yaitu KH. Hasyim Asy'ari, pendiri Nahdlatul Ulama. Masa kecilnya selain di Jakarta ikut ayahnya, ia banyak mengenyam pendidikan di pondok pesantren. Hingga pada tahun 1953, ia masuk SMEP (Sekolah Menengah Ekonomi Pertama) Gowangan, sambil nyantri di pesantren Krapyak. Walaupun sekolah tersebut adalah sekolah yang dikelola oleh Gereja Katolik Roma, namun sepenuhnya menggunakan kurikulum sekuler. Awalnya memang nyantri di pesantren Krapyak, akhirnya ia pindah di rumah Haji Junaidi, seorang pimpinan lokal Muhammadiyah. Namun, Gus Dur tetap ikut kegiatan rutin setelah shalat subuh mengaji kepada KH. Ali Maksum Krapyak. Setamat dari SMEP, Gus Dur melanjutkan belajarnya di Pesantren Tegalrejo Magelang yang diasuh oleh K.H Chudhari. Di sana ia banyak belajar ritus-ritus sufi dan menanamkan praktik ritual mistik. Selain belajar ilmu agama, ia juga membaca seluruh koleksi buku-bukunya dari Yogyakarta, sehingga membuat santri lainnya terheran-heran.

Pada tahun 1959, Gus Dur pindah ke Jombang dan belajar kepada Kiai Wahab Chasbullah dengan pendekatan sufistik. Ia juga sembari mengajar dan menjadi kepala sekolah. Pada tahun 1963, ia mendapatkan kesempatan untuk melanjutkan studinya di Al-Azhar, Kairo Mesir. Sedangkan pada tahun 1966, ia pindah kuliah ke Bagdad dan lulus pada tahun 1970 sehingga menjadi ahli sejarah Islam di Indonesia. 


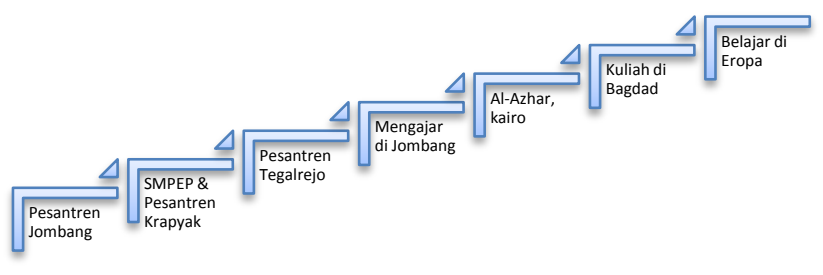

Bagan 5: perjalanan pendidikan Gus Dur

Niatnya untuk belajar tidak berhenti sampai di Bagdad, ia ingin melanjutkan ke Leiden, Belanda. Namun sayang, ijazahnya tidak diterima. Akhirnya ia berada di Belanda selama 6 bulan belajar dengan masyarakat Eropa, 4 bulan ke Jerman, 2 bulan ke prancis dan akhirnya Pulang ke Indonesia. Pada tahun 1979 Gus Dur ditawari untuk belajar ke Universitas Mcgill di Australia untuk mendapatkan gelar doktornya, namun gagal karena promotornya tidak sanggup dan menganggap bahwa ia tidak membutuhkan gelar tersebut, bahkan beberapa disertasi calon doktor dari Australia justru dikirimkan kepadanya untuk dikoreksi.

Keempat, pekerjaan. Dengan bekerja menurut Notoatmodjo (2003), seseorang dapat berbuat sesuatu yang bernilai, bermanfaat, memperoleh pengetahuan yang baik tentang suatu hal sehingga lebih mengerti dan akhirnya mempersepsikan sesuatu dengan positif. Perjalanan karir Gus Dur sangat panjang, ia menjadi guru, aktivis sosial, menjadi ketua PBNU, hingga menjadi presiden. Di sela-sela itu semua pekerjaan yang jarang ditinggalkan Gus Dur adalah menulis. Ia menulis di berbagai media, buku pengantar, makalah dan lain sebagainya.

Karir pertama Gus Dur adalah mengajar dan menjadi kepala sekolah di tambak beras Jombang. Ketika belajar di Kairo, ia juga bekerja di Kedutaan besar Republik Indonesia bidang protokloler dan konsuler pada tahun (1964-1966). Saat ia melanjutkan kuliah di Bagdad, Gus Dur juga bekerja di kantor pedagang kain Ar-Ramadhani, dari pukul 11.00 hingga pukul 14.00 siang waktu setempat, waktu sorenya ia pakai untuk ke perpustakaan.

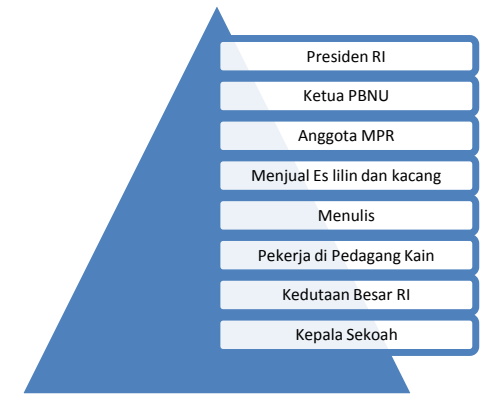

Bagan 6: Perjalanan Karir atau pekerjaan Gus Dur 
Sepulang dari Eropa Gus Dur bekerja di LP3ES, sehingga ia banyak berkunjung ke pesantren-pesantren. Ia juga banyak mengisi ceramah dan seminar. Karena kondisi ekonominya kurang memadai karena mengandalkan honor dari menulis, pun saat itu sudah mempunyai anak, Gus Dur menjual kacang dan es lilin. Gus Dur juga melakukan pekerjaan domestik, mencuci dan mengepel. Karir Gus Dur terus menanjak, ia bahkan pernah menjadi anggota MPR, menjadi ketua PBNU hingga menjadi presiden.

\section{Faktor Eksternal}

Faktor eksternal merupakan faktor yang berasal dari luar diri seseorang dalam menciptakan atau menemukan suatu hal. Faktor eksternal sangat erat kaitannya dengan faktor internal. Faktor eksternal bisa terdiri dua hal, yaitu informasi dan pengalaman.

Pertama, informasi. Informasi yang diperoleh seseorang sangat beragam melalui panca indra. Bagi Notoatmodjo (2003), semakin banyak informasi dapat memengaruhi atau menambah pengetahuan seseorang dan dengan pengetahuan menimbulkan kesadaran yang akhirnya seseorang akan berperilaku sesuai dengan pengetahuan yang dimiliki. Semakin banyak informasi yang diterima akan menentukan bagaimana ia menginterpretasi sesuatu hal.

Informasi pertama yang diperoleh oleh Gus Dur adalah khazanah keilmuan pesantren. Ia sangat dekat dengan tokoh bangsa, baik ayahnya sendiri ataupun kakeknya yang merupakan pendiri Nahdlatul Ulama. Ia sangat dekat dengan perdebatan-perdebatan di dunia pesantren, hingga pergolakan saat masa perjuangan membangun bangsa Indonesia ini. Informasi kedua yang diperoleh oleh Gus Dur adalah dari buku. Sedari kecil, ia sudah menjadi kutu buku. Bahkan ketika ia berada di Yogyakarta, ia sudah membaca buku-buku kiri. Minatnya membaca buku tidak pernah redup, bahkan ketika ia sudah tidak menjabat menjadi Presiden Republik Indonesia.

Kedua, pengalaman. Pengalaman merupakan suatu peristiwa yang pernah dialami seseorang. Bagi Azwar (2005), pengalaman merupakan suatu peristiwa yang pernah dialami seseorang. Bagi Notoatmodjo (2005), pengalaman yang dimiliki seseorang merupakan faktor yang sangat berperan dalam menginterpretasikan stimulus yang kita peroleh. Pengalaman seseorang diperoleh sedari ia lahir sampai ia wafat. Begitu juga dengan Gus Dur, pengalaman-pengalamannya pun diperoleh semasa 
hidupnya. Penulis hanya merangkum pengalaman-pengalaman Gus Dur yang terekam di berbagai literasi. Misalnya pada masa umur 4 tahun, Gus Dur pergi ke Jakarta ikut ayahnya, Wahid Hasyim. Ayahnya menjadi tokoh nasional, menggantikan kakeknya KH. Hasyim Asy'ari yang ditawari jabatan sebagai ketua Shumbu (bidang keagamaan) untuk memperbaiki hubungan pesantren dengan Jepang. Karena Wahid Hasyim berada di orbit gerakan nasionalis bersama Soekarno, Mohammad Hatta, Tan Malaka. Gus Dur sudah banyak bersinggungan pada masa kecilnya dengan para tokoh nasionalnya, bahkan Tan Malaka dipanggil olehnya dengan Paman Husen.

Setelah Pemerintah Belanda mengakui berdirinya Republik Indonesia Serikat, kemudian Wahid Hasyim kembali ke Jakarta untuk terlibat pemerintahan. Begitu juga Gus Dur ikut ayahnya ke Jakarta. Pada waktu itu, Gus Dur bertemu dengan para tamu ayahnya dari berbagai macam latar belakang dan bahasa. Gus Dur pun terkadang diajak ayahnya untuk mengikuti aktivitasnya, misalnya aktivitas NU. Pada 18 April 1953, Gus Dur diajak ayahnya ke pertemuan NU di Sumedang, namun terjadi kecelakaan. Walaupun Gus Dur lahir dari keluarga pesantren, bahkan pendiri organisasi Nahdlatul Ulama, namun ia tidak hanya belajar khazanah keilmuan pesantren. Gus Dur banyak belajar dari tokoh Muhammadiyah yaitu H. Junaidi, sekaligus tinggal di rumahnya. Ia juga belajar berbagai macam wacana baik keislaman, filsafat atau lainnya.

Pengalaman Gus Dur yang membentuk dirinya juga dari pengalaman di lingkungan pesantren. Pada suatu ketika, sebagaimana ditulis oleh Nur Khalik Ridwan dalam tulisannya "Gus Dur di Tegalrejo (1957-1959)", Gus Dur juga pernah diajak diskusi dengan Kiai Chudhori, tentang apa kira-kira yang akan dilakukan untuk mensyukuri akhir tahun pelajaran, atau imtihan. Gus Dur mengusulkan diundangnya masyarakat yang dulu pernah datang untuk menanyakan soal bondo desa. Kiai Chudori pun setuju, maka setelah itu, imtihan yang panitianya dilakukan Gus Dur, salah satunya adalah nanggap wayang, pun ada rangkaian-rangkaian mujahadah dan doa. ${ }^{11}$ Pengalaman yang membentuk pemikiran Gus Dur adalah situasi, yaitu saat orde baru. Situasi itulah yang membuat Gus Dur banyak melakukan kritik terhadap praktik demokrasi, pemanfaatan kelompok agama oleh pemerintah dan lain sebagainya. Hingga Gus Dur pernah mendirikan Forum Demokrasi (Fordem).

${ }^{11}$ Nur Khalik Ridwan, Gus Dur di Tegalrejo, (1957-1959), diterbitkan di facebooknya dan dimuat di gusdurian.net.

Jurnal Tashwirul Afkar Vol. 38, No. 01, Tahun 2020. 


\section{Harga Diri Gus Dur}

Dalam kajian persepsi diri, setelah adanya konsep diri kemudian selanjutnya adalah harga diri (self esteem). Harga diri diartikan sebagai penilaian diri sendiri. harga diri seseorang bisa lebih tinggi ataupun lebih rendah daripada orang lain. penilaian tersebut berada di sistem kognitif, maka penilaian seseorang terhadap diri sendiri sangat tergantung kepada perubahan konsep diri penilaian terhadap atribut yang melekat berubah, maka harga diri seseorang juga dapat berubah. Suyando dkk (2011), mengutip Brigham (1991:104) menjelaskan bahwa harga diri merupakan "the evaluative part of the self-concept".

Bagi Suyanto, seseorang akan melakukan evaluasi terhadap dirinya sendiri setelah memahami konsep dirinya. Untuk melakukan evaluasi diri diperlukan suatu standar penilaian yang digunakan sebagai patokan apakah dirinya itu lebih baik atau lebih buruk dari self idealnya. Cara untuk mengevaluasi bagi Suyanto ada empat hal. Pertama, self yang Anda inginkan, artinya Anda menginginkan atau memiliki harapan agar diri Anda seperti apa. Kedua, karakteristik yang penting orang lain yang disebut juga ideal self-others. Ketiga, karakteristik yang seharusnya Anda miliki berkaitan dengan tugas, tanggung jawab dan kewajiban terhadap orang lain (ough self). Keempat, karakteristik yang penting bagi orang lain yang Anda rasakan telah dilakukan di atas sebenarnya merupakan tindakan seseorang ketika melihat kesenjangan antara konsep diri aktual kita dengan petunjuk diri kita. $^{12}$

Jika menggunakan tawaran Suyanto untuk melihat harga diri Gus Dur sangatlah sulit. Untuk melihat konsep dirinya Gus Dur, penulis memakai tawarannya Brehm dan Kassin (1996:56). Mereka mendefinisikan harga diri adalah "an affective component of the self, consisting of a person's positive and negative self evaluation". Dari definisi tersebut, dapat kita pahami bahwa harga diri merupakan komponen afektif dari self, yang berupa evaluasi diri seorang baik positif dan negatif. Harga diri yang didefinisikan oleh Brehm dan Kassim tidak melulu evaluasi dari seorang tersebut, melainkan dari penilaian orang lain. Harga diri dapat dipahami dari cara pandang orang lain berkaitan dengan kehidupan kesehariannya. Ketika ada penilaian baik dari orang lain, ia akan cenderung bahagia, sehat, sukses, dan produktif. Begitu juga Gus Dur, harga dirinya bisa dilihat dari keseharian, kebijakan dan tindakannya. Harga diri yang dimiliki Gus Dur lebih pada posisinya di sosial masyarakat, karena yang mengetahui harga diri pribadinya Gus Dur adalah

${ }^{12}$ Suyanto, dkk. Pengantar Psikologi Sosial, (Surabaya: Pusat Penerbitan dan Percetakan Unair (AUP), 2012), h. 35. 
dirinya sendiri. Orang lain bisa mengkaji harga diri Gus Dur melalui berbagai macam pikiran, tindakan, kebijakan dan perilakunya.

Heru Prasetia dalam tulisannya "Sketsa Nilai dan Pemikiran Gus Dur" menjelaskan bagaimana para sahabat, murid Gus Dur merumuskan nilainilai perjuangannya. Sekitar pada akhir tahun 2011, sejumlah sahabat dekat dan murid-murid Gus Dur, seperti KH. Mustofa Bisri, Ahmad Tohari, Marsilam Simanjuntak, dan lain-lain berkumpul dalam sebuah simposium tentang Gus Dur di Jakarta. Simposium tersebut kemudian berhasil merumuskan apa yang kemudian kita kenal dengan 9 nilai utama Gus Dur. Nilai-nilai tersebut disarikan dari berbagai perjumpaan, kesaksian, tindakan, dan tentu saja beragam percikan pemikiran Gus Dur yang tersebar di berbagai tempat dan ingatan. Kesembilan nilai itu yaitu ketauhidan, kemanusiaan, keadilan, kesetaraan, pembebasan, kesederhanaan, persaudaraan, kesatriaan, dan kearifan lokal. ${ }^{13}$ Dari kesembilan nilai tersebut namun ada sebagian yang masuk dalam presentasi Gus Dur di publik. Penulis memilah dan memilih apa yang menjadi harga diri Gus Dur dan mana yang menjadi presentasi diri Gus Dur.

Ketauhidan menjadi landasan utama pemikiran Gus Dur. Ketauhidan juga menjadi harga diri Gus Dur. Ketauhidan dianggap sebagai sifat Ilahi yang diwujudkan dalam perilaku dan perjuangan sosial, politik, ekonomi, dan kebudayaan dalam menegakkan nilai-nilai kemanusiaan. Kalau kita lihat pemikiran Gus Dur tentang keislaman, bukan hanya sebatas mengurusi urusan peribadahan di dalam masjid, namun dijadikan sebagai solusi atas permasalahan yang berkembang di masyarakat. Misalnya, dengan semangat ketauhidan dan keislaman, Gus Dur memperjuangkan keadilan sosial, kemanusiaan dan lain sebagainya. Gus Dur bukan hanya membela kelompok-kelompok minoritas, melainkan yang dilakukannya adalah upaya untuk membela kemanusiaan mereka yang mengalami represi. Gus Dur sangat membela mereka yang mengalami kekerasan, karena adanya sentimen agama. Dalam membela kemanusiaan, Gus Dur membela tanpa syarat. Memuliakan manusia sama dengan memuliakan Penciptanya. Begitu juga ketika ada yang menistakan manusia, berarti ia sedang merendahkan dan menistakan Tuhan. Kemanusiaan bersumber dari pandangan ketauhidan. Manusia merupakan makhluk Tuhan yang paling mulia yang dipercaya untuk mengelola dan memakmurkan bumi. Kemanusiaan menjadi cerminan sifat-sifat ketuhanan. ${ }^{14}$

Dur/

${ }^{13}$ http://www.gusdurian.net/id/article/headline/Sketsa-Nilai-dan-Pemikiran-Gus-

14http://www.gusdurian.net/id/9-Nilai-Utama-Gus-Dur/

Jurnal Tashwirul Afkar Vol. 38, No. 01, Tahun 2020. 
Salah satu harga diri Gus Dur yang dipegang teguh adalah adanya keadilan sosial. Misalnya ketika ia menjadi Presiden, kebijakankebijakannya tidak mendiskriminasikan kelompok tertentu. Justru kebijakannya mengakomodir kelompok yang selama ini terpinggirkan oleh sistem. Gus Dur sangat memegang teguh Undang-Undang Dasar 1945, memperlakukan semua warga negara sama di mata hukum. Gus Dur saat menjadi Presiden RI ke 4, pada tanggal 17 Januari 2000, ia mengambil keputusan bersejarah dan monumental. Ia mengeluarkan Instruksi Presiden (Inpres) No. 6/2000 yang isinya mencabut Inpres No. 14/1967. Kebijakan Gus Dur tersebut melahirkan kebebasan etnis Tionghoa dalam menjalankan ritual keagamaan, adat istiadat, serta memperbolehkan pengekspresian terhadap kebudayaan di Indonesia. Kebijakan Gus Dur tersebut bertujuan untuk menerapkan nilai-nilai yang terkandung dalam spirit anti rasisme memantul ke dalam jiwa dan kehidupan seluruh elemen bangsa. ${ }^{15}$

Gus Dur rela mengambil tanggung jawab untuk mewujudkan keadilan di tengah-tengah masyarakat. Keadilan berlandaskan dari pandangan bahwa martabat kemanusiaan hanya bisa dipenuhi dengan adanya keseimbangan, kelayakan, dan kepantasan dalam kehidupan masyarakat. Bagi Gus Dur, keadilan tidak sendirinya hadir di dalam realitas kemanusiaan dan karenanya harus diperjuangkan. Ketika ada kelompok yang diperlakukan tidak adil, maka kita harus bertanggung jawab untuk membelanya. ${ }^{16}$

Kearifan tradisi menjadi harga diri Gus Dur. Menjadi harga dirinya, karena hidup dalam lingkungan pesantren yang menjunjung kearifan lokal. Kalau membaca pemikirannya Gus Dur, sangat memegang teguh kearifan lokal. Dengan memegang adagium, "al-muhafadhah 'alā qadim al-shalih wal akhdzu bi al-jadid al-ashlah" (memelihara yang lama yang masih baik dan mengambil yang baru yang lebih baik), kearifan lokal sangat diperhatikan oleh Gus Dur. Atas dasar itulah, Gus Dur dalam pemikirannya yang dituangkan dalam tulisan atau tindakan sangat menjunjung kearifan lokal. Bagi Greg Barton dalam tulisannya "Biografi Gus Dur" menyatakan bahwa Gus Dur terbuka untuk belajar tradisi lain. Hal demikian banyak dilakukan oleh orang-orang Nahdlatul Ulama.

Cendekiawan Islam seperti Gus Dur dan kebanyakan ulama NU terbuka untuk belajar dari tradisi lain, termasuk tradisi-tradisi yang terdapat di jantung spiritualitas Jawa dan Asia Tenggara sebelum datangnya

${ }^{15}$ Ali Mustajab, Kebijakan Politik Gus Dur Terhadap China Tionghoa di Indonesi (In Right, Jurnal Agama dan Hak Azazi Manusia, 2015), h.158

16http://www.gusdurian.net/id/9-Nilai-Utama-Gus-Dur/ 
Islam. Bagi Greg Barton, hal itu sejalan dengan keyakinan yang dianut secara luas oleh kaum tradisionalis bahwa segala sesuatu yang tidak secara jelas diharamkan oleh Al-Qur'an dan sunnah nabi maka hal itu diizinkan selama terdapat konsistensi dengan prinsip-prinsip dan nilai-nilai yang terkandung dalam Al-Qur'an dan sunnah nabi. Sebaliknya, bagi Greg Barton bagi kebanyakan kaum cendekiawan konservatif dengan latar belakang modernis, jika sesuatu tidak ada acuannya dalam Al-Qur'an ataupun sunnah nabi maka hal itu harus diperlakukan secara hati-hati; dan jika sesuatu mengandung unsur-unsur yang bertentangan dengan monoteisme Islam maka hal itu juga harus dihindari. ${ }^{17}$

Gus Dur menggerakkan kearifan lokal dan menjadikannya sebagai sumber gagasan dan pijakan sosial-budaya-politik dalam membumikan keadilan, kesetaraan, dan kemanusiaan, tanpa kehilangan sikap terbuka dan progresif terhadap perkembangan peradaban. ${ }^{18}$ Termasuk dalam pemikirannya terhadap keislaman, hingga Gus Dur mengeluarkan gagasan pribumisasi Islam. Bahkan dalam tulisannya yang berjudul "Pendidikan Islam Harus Beragam" Gus Dur juga mengutamakan tentang kearifan lokal.

Pembebasan juga menjadi salah satu harga diri yang dipegang oleh Gus Dur. Tidak dapat dipungkiri, bahwa pemikiran Gus Dur juga terpengaruh dengan situasi Orde Baru. Pemerintah Orde Baru yang mengatakan dirinya demokratis, justru menciptakan Undang-Undang untuk menjerat siapa saja yang mengkritik. Pada situasi tersebut, hampir tidak ada orang yang berani mengemukakan kebenaran.

Atas situasi tersebut ia ingin membebaskan jeratan Orde Baru yang mengekang kebebasan berpendapat. Gus Dur mengeluarkan gagasan dan pemikirannya tentang demokrasi yang pantas diterapkan di Indonesia. Gus Dur memandang demokrasi sebagai suatu proses atau budaya yang terus menerus dan tidak hanya diukur dari segi kelembagaannya saja yang diterapkan selama orde baru. ${ }^{19}$ Gus Dur semasa hidupnya mendorong tumbuhnya jiwa-jiwa merdeka yang mampu membebaskan dirinya dan manusia lain. Berbeda tidak menjadi penghalang bagi tumbuhnya persaudaraan. Gus Dur telah mencontohkan bagaimana persaudaraan dengan lintas iman, lintas budaya diteladankan. Dengan mewujudkan persaudaraan, Gus Dur sedang memproklamirkan penghargaan

${ }^{17} \mathrm{Greg}$ Barton, The Authorized Biography of Abdurrahman Wahid, (Yohyakarta: LKIS Group, 2003), h. 68.

18 http://www.gusdurian.net/id/9-Nilai-Utama-Gus-Dur/

${ }^{19}$ Indo Santalia, "K.H Abdurrahman Wahid: Agama dan Negara, Pluralisme, Demokratisasi, dan Pribumisasi", Jurnal Al-Adyaan, Volume 1, Nomor 2, Desember 2015, h. 144.

Jurnal Tashwirul Afkar Vol. 38, No. 01, Tahun 2020. 
kemanusiaan, keadilan, dan kesetaraan di masyarakat sehingga tidak akan mendiskriminasikan kelompok lain.

\section{Presentasi Pemikiran Gus Dur Terhadap Pendidikan Islam}

Strategi presentasi diri merupakan usaha kita untuk membentuk kesan orang lain dalam cara tertentu dalam rangka untuk mendapatkan pengaruh, kekuatan, simpati, dan perhatian. Presentasi diri juga bisa disebut manajemen kesan/ impression management. Tujuan strategi presentasi diri sangat beragam, yaitu ingratiation dan self-promotion. Ingratiation merupakan tindakan yang dilandasi motivasi untuk mencapai sesuatu (to get along) dan disukai orang lain. Tujuan kedua adalah self-promotion, yaitu suatu istilah yang menggambarkan tindakan-tindakan yang dimotivasi oleh keinginan untuk menjadi tertentu (to get ahead) dan disegani (respected) atas kompetensi kita. Tujuan-tujuan ini menjadi dasar dalam perilaku sosial yang dikembangkannya pada tahap selanjutnya. ${ }^{20}$

Bagi Gus Dur banyak menulis tentang pemikiran keislaman, demokrasi, dan khususnya dalam pemikirannya tentang pendidikan memiliki strategi presentasi tertentu. Bagi penulis, Gus Dur banyak menulis karena ingin mencapai sesuatu (to get along). Tulisan dijadikan sebagai media, pun jabatan yang dimilikinya. Tujuannya jelas yang dijalankan adalah sesuai dengan konsep dirinya yang tertuang dalam harga diri Gus Dur.

Pada bagian ini, penulis akan fokus bagaimana presentasi pemikiran Gus Dur terutama dalam bidang pendidikan Islam. Gus Dur pada 21 Desember 2002, menulis di koran Kedaulatan Rakyat dengan judul "Pendidikan Islam Harus Beragam". Tulisan tersebut merefleksikan perjalanannya menghadiri dialog di Beirut (Lebanon) pada tanggal 13-14 Desember 2002. Gus Dur sendiri dalam dialog tersebut menuliskan makalah tentang pondok pesantren dari berbagai sudut. Ada banyak pemikiran Gus Dur yang tertuang dalam sebuah kolom, dan ada kaitannya dengan harga diri yang ingin dicapai oleh Gus Dur.

Melalui tulisannya yang berjudul "Pendidikan Islam Harus Beragam" tersebut, ada banyak tujuan Gus Dur yang tertuang dalam tulisan tersebut. Selain ingin mewujudkan sesuatu yang dicapai dalam tulisannya tersebut, Gus Dur juga menggambarkan tindakan-tindakan yang dimotivasi oleh keinginan untuk menjadi tertentu. Dalam tulisan tersebut, Gus Dur ingin mengembalikan tujuan pendidikan Islam yang utama. Pendidikan Islam

${ }^{20}$ Suyanto dkk., Pengantar Psikologi Sosial (Surabaya: Pusat Penerbitan dan Percetakan Unair (AUP), 2012), h. 48. 
bukan hanya yang berada di balik tembok dan bangku sekolah, melainkan pendidikan Islam beragam di masyarakat. Keberagaman pendidikan tersebut terwujud dalam aktivitas keagamaan masyarakat, seperti arisan, pengajian dan lain sebagainya. Pendidikan Islam bukan hanya sebatas pendidikan formal, melainkan pendidikan non formal.

Presentasi kedua dari gagasan tulisan tersebut, Gus Dur ingin mendorong bahwa pendidikan Islam bukan hanya mengajarkan ajaran formal Islam, namun juga harus memerhatikan perubahan yang ada di masyarakat. Termasuk, pendidikan Islam juga harus merespon tantangan modernisasi. Tantangan tersebut bisa berwujud pengentasan kemiskinan, pelestarian lingkungan hidup dan lain sebagainya.

Strategi presentasi dari gagasan Gus Dur ingin mendorong pendidikan Islam yang merespon tantangan modernisasi, namun jangan sampai melupakan kearifan lokal. Gagasan Gus Dur dalam tulisan tersebut adalah studi kawasan. Tentunya kawasan satu dengan kawasan lainnya sangat berbeda, sehingga corak pendidikan Islam haruslah beragam antar kawasan.

Presentasi pemikiran seseorang pastinya ingin mewujudkan ide-ide yang ingin dicapainya. Ide-ide yang ingin dicapainya bagi penulis adalah harga diri seseorang. Apabila ide yang ingin dicapai tidak tercapai, ia akan melakukan evaluasi terhadap dirinya atau terhadap realitas sosial yang ada di masyarakat. Termasuk pemikiran Gus Dur tentang pendidikan Islam yang tertuang dalam tulisan, sangat erat kaitannya dengan ide-ide yang ingin dicapainya (harga diri). Penulis berangkat dari konsep diri Gus Dur secara umum, dan menganalisis harga diri Gus Dur yang ingin dicapainya juga secara umum. Namun pada bagian ini, penulis akan menganalisis dari tulisannya Gus Dur dan memuat harga diri apa saja.

Pendidikan Islam bagi Gus Dur harus tetap mengajarkan ajaran-ajaran formal Islam sebagai sebuah keharusan yang diterima. Ajaran formal yang dimaksud oleh Gus Dur adalah ajaran bagaimana cara melaksanakan ibadah sesuai dengan syariat Islam. Bahkan Gus Dur menyatakan bahwa ajaran formal Islam harus diutamakan dalam pendidikan Islam.

“...tentu saja ajaran-ajaran formal Islam harus diutamakan, dan kaum muslimin harus dididik mengenai ajaran-ajaran agama mereka. Yang diubah adalah cara penyampaiannya kepada peserta didik, sehingga mereka akan mampu memahami dan mempertahankan "kebenaran". Bahwa hal ini memiliki validitas sendiri, dapat dilihat pada kesungguhan anak-anak muda muslimin terpelajar untuk menerapkan apa yang mereka anggap sebagai “ajaran-ajaran yang benar" tentang Islam." 21

${ }^{21}$ Abdurrahman Wahid, Pendidikan Islam Harus Beragam, Kedaulatan Rakyat, 21 Desember 2002.

Jurnal Tashwirul Afkar Vol. 38, No. 01, Tahun 2020. 
Harga diri tentang ketauhidan sedang Gus Dur sampaikan dalam gagasan tersebut. Seorang peserta didik memiliki nilai ketauhidan apabila memiliki keimanan kepada Allah Swt. sebagai Dzat yang Maha Ada. Materi tentang keimanan serta ilmu serumpun memang sudah selayaknya diajarkan dalam dunia pendidikan Islam, termasuk bagaimana cara beribadah kepada Allah Swt.

Gus Dur juga menyatakan dalam tulisan tersebut bahwa ajaran-ajaran formal Islam dipertahankan sebagai sebuah keharusan yang diterima kaum muslimin di berbagai penjuru dunia. Memang sudah semestinya, hal yang wajib disampaikan dalam pendidikan Islam adalah ajaran-ajaran formal. Hingga peserta didik tersebut mampu memahami dan mempertahankan kebenaran. Gus Dur mencontohkan bagaimana anak-anak muda muslimin terpelajar dalam menerapkan apa yang mereka anggap sebagai "ajaranajaran benar". Contoh paling mudah bagi Gus Dur adalah menggunakan tutup kepala di sekolah non-agama, yang di negeri ini baginya dikenal dengan nama jilbab.

Setelah ajaran-ajaran formal diberikan kepada peserta didik, pendidikan Islam juga harus menjawab kenyataan yang ada di masyarakat. Pendidikan Islam juga harus menjawab tantangan modernisasi. Gus Dur mencontohkan seperti pengentasan kemiskinan, pelestarian lingkungan hidup dan lainnya. Gus Dur mengeluarkan gagasan tersebut berdasarkan nilai ketauhidan. Ketauhidan yang bersifat Ilahi apabila diwujudkan dalam perilaku dan perjuangan sosial, politik, ekonomi dan kebudayaan dalam menegakkan nilai-nilai kemanusiaan.

Gus Dur mengawali tulisan "Pendidikan Harus Beragam" dengan menjelaskan pondok pesantren, selain memang makalahnya bertema pesantren. Baginya, pesantren merupakan lembaga kultural yang menggunakan simbol-simbol budaya Jawa dan sebagai agen pembaharuan yang memperkenalkan gagasan pembangunan pedesaan. Pesantren menurut Gus Dur juga sebagai pusat kegiatan belajar masyarakat. Gus Dur mencirikan bahwa pesantren sebagai ada campur tangan budaya lokal dengan menggunakan simbol-simbol budaya Jawa. Namun, perannya sebagai lembaga pendidikan Islam tidak ditinggalkan. Sebagai pusat pendidikan Islam di masyarakat, pesantren tidak lepas dari budaya setempat. Begitu juga dengan gagasan Gus Dur terkait pendidikan Islam, juga harus memerhatikan perubahan yang ada di kawasan masing-masing. Ajaran-ajaran formal Islam dipertahankan sebagai sebuah keharusan yang diterima kaum muslimin di berbagai penjuru dunia. Tetapi di sini juga terdapat benih-benih perubahan yang membedakan antara kaum muslimin 
di sebuah kawasan dengan kaum muslimin lainnya dari kawasan yang lain. ${ }^{22}$

Setiap kawasan memiliki tantangan bahkan tradisi masing-masing sehingga berbeda antara pendidikan Islam di satu kawasan dengan kawasan lainnya. Bahkan Gus Dur pernah mengajukan sebuah makalah kepada Universitas PBB di Tokyo pada tahun 1980-an. Gus Dur menawarkan adanya "study kawasan" Islam di lingkungan Afrika Hitam, budaya Afrika Utara dan negeri-negeri Arab, budaya Turki-Persia-Afghan, budaya Islam di Asia Selatan, budaya Islam di Asia Tenggara dan budaya minoritas muslim di kawasan-kawasan industri maju. Sudah tentu, bagi Gus Dur, kajian kawasan diteliti bersamaan dengan kajian Islam klasik.

Dengan memegang adagium al-muhafadhah 'ala qadim al-shalih wa alakhdu bi al-jadid al-ashlah (memelihara yang lama yang masih baik dan mengambil yang baru yang lebih baik) Gus Dur menawarkan gagasan modernisasi yang tidak asal menerima gagasan dari luar, namun memerhatikan kearifan lokal. Karena setiap kawasan atau daerah memiliki kearifan lokal sendiri, bagi kawasan yang mayoritas Islam mungkin cocok dengan menggunakan pengajian, tradisi majelis shalawat dan lain sebagainya. Berbeda pula dengan kawasan perkotaan, barangkali cocok dengan arisan. Gus Dur memberikan contoh gerakan shalawat nabi. Baginya, shalawat nabi terjadi demikian cepat di mana-mana. Gus Dur menyatakan bahwa "kenyataan yang diam" seperti itu sebenarnya berbicara sangat nyaring, namun kita yang tidak dapat menangkapnya. Shalawat nabi merupakan salah satu bentuk pendidikan Islam.

“...Seorang warga Islam yang memperoleh kedamaian dengan ritual memuja nabi itu, dengan sendirinya berupaya menyesuaikan hidupnya dari pola hidup nabi yang diketahuinya, yaitu kepatuhan kepada ajaran Islam. Ritual itu tentu saja akan menyadarkan kembali orang tersebut kepada kehidupan agama walaupun hanya bersifat parsial (Juz'i) belaka. Hal inilah yang seharusnya kita pahami sebagai "kenyataan" sosial yang tidak dapat kita pungkiri dan diabaikan." ${ }^{23}$

Setiap daerah memiliki budaya pendidikannya masing-masing sehingga pendidikan Islam tidak harus satu corak antara satu kawasan dengan kawasan yang lainnya. Pada prinsipnya, pendidikan Islam mengajarkan ajaran formal Islam. Dalam tulisannya "Pendidikan Islam Harus Beragam" Gus Dur ingin menyadarkan kita bahwa pendidikan Islam bukan hanya yang ada di tembok sekolah formal. Kenyataan yang ada di

${ }^{22}$ Abdurrahman Wahid, Pendidikan Islam Harus Beragam, Kedaulatan Rakyat, 21 Desember 2002.

${ }^{23}$ Abdurrahman Wahid, Pendidikan Islam Harus Beragam, Kedaulatan Rakyat, 21 Desember 2002.

Jurnal Tashwirul Afkar Vol. 38, No. 01, Tahun 2020. 
masyarakat pendidikan Islam sangat beragam. Sebenarnya pendidikan sangat banyak dijalankan di masyarakat, bahkan berserak-serak di seluruh dunia.

"Pendidikan Islam tidak hanya disampaikan dalam ajaran-ajaran formal Islam di sekolah-sekolah agama atau madrasah belaka, melainkan juga melalui sekolahsekolah non agama yang berserak-serak di seluruh penjuru dunia. Tentu saja kenyataan seperti itu tidak dapat diabaikan di dalam penyelenggaraan pendidikan Islam di negeri manapun. Hal ini yang harus diterima sebagai kenyataan hidup kaum muslimin di mana-mana adalah respon umat Islam terhadap tantangan modernisasi. Tantangan seperti pengentasan kemiskinan, pelestarian lingkungan hidup, dan sebagainya, adalah respon yang tak kalah bermanfaatnya bagi pendidikan Islam, yang perlu kita renungkan secara mendalam."24

Gus Dur berusaha membuka kenyataan bahwa pendidikan Islam tersebar di masyarakat, sesuai dengan kawasannya masing-masing. Seharusnya yang diperhatikan bukan hanya pendidikan Islam yang ada di sekolah formal saja, melainkan juga pendidikan yang telah lama dijalankan oleh masyarakat. Gagasan Gus Dur tersebut memuat nilai pembebasan, yaitu ingin mendobrak paradigma umum masyarakat yang menganggap bahwa pendidikan Islam hanya terbatas di dalam madrasah dan sekolah formal. Gus Dur juga berusaha ingin mewujudkan nilai pembebasan bahwa pendidikan Islam bukan hanya sebatas mengajarkan ajaran formal Islam, melainkan menjawab tantangan pengentasan kemiskinan, pelestarian lingkungan hidup dan lain sebagainya. Gagasan ini sebenarnya tidak jauh dengan gagasan keislaman Gus Dur tentang universalisme dan kosmopolitanisme Islam.

Pendidikan Islam bagi Gus Dur harus sanggup "meluruskan" respon terhadap modernisasi itu. Namun, bagi Gus Dur kesadaran kepada hal itu justru belum ada dalam pendidikan Islam di mana-mana. Untuk membuat kesadaran struktural sebagai bagian natural dari perkembangan pendidikan Islam, Gus Dur menawarkan untuk menyimak perkembangan pendidikan Islam di berbagai tempat. Selain itu, membuat peta yang jelas tentang konfigurasi pendidikan Islam itu sendiri. Hal demikian bagi Gus Dur merupakan pekerjaan rumah, yang mau tidak mau harus ditangani dengan baik.

\section{Kesimpulan}

Pemikiran Gus Dur tentang keberagaman pendidikan Islam dalam menjawab tantangan modernisasai tidak begitu saja muncul. Mengeluarkan pemikiran pendidikan Islam semacam itu, merupakan perwujudan dari

${ }^{24}$ Abdurrahman Wahid, Pendidikan Islam Harus Beragam, Kedaulatan Rakyat, 21 Desember 2002. 
konsep diri dan harga diri yang telah dibangun oleh Gus Dur. Dari harga diri, kemudian muncul presentasi yang berupa pemikiran, tindakan dan kebijakan. Ada banyak hal yang memengaruhi konsep diri Gus Dur, mulai dari guru, lingkungan, buku, kitab kuning, situasi dan lain sebagainya. Dari stimulus dan informasi yang telah diterimanya, kemudian membuat harga diri Gus Dur. Misalnya pengalamannya di pesantren Tegal Rejo Magelang, Gus Dur mendapatkan pengalaman berharga tentang kebudayaan dari Kiai Chudhori. Dari pengalaman tersebut kemudian tumbuhlah harga diri yaitu kearifan lokal. Contoh lain, Gus Dur tumbuh dalam situasi Orde Baru. Pada waktu itu masyarakat dibatasi kebebasan berpendapat dan berserikat. Dari pengalaman tersebut, memunculkan harga diri pembebasan, bahwa manusia memiliki tanggung jawab untuk menegakkan kesetaraan dan keadilan, untuk melepaskan diri dari berbagai bentuk belenggu.

Dari harga diri yang sudah dibentuk dari konsep diri tersebut, kemudian muncullah tampilan yang berupa pemikiran yang dituangkan dalam tulisan atau seminar. Atau bentuk presentasi dari konsep diri-harga diri dituangkan dalam bentuk kebijakan dan tindakan Gus Dur. Begitu juga dengan konsep pendidikan Islam Gus Dur, merupakan representasi dari harga diri yang telah lama dibentuk dari pengalaman dan informasi yang telah diterima. 


\section{Daftar Pustaka}

Ahmad, Munawar, Ijtihad Politik Gus Dur, Analisis Wacana Kritis, Yogyakarta: LKiS, 2010.

Aziz, Rosmiaty, Ilmu Pendidikan Islam. Yogyakarta: Sibuku, 2019.

Barton, Greg, The Authorized Biography of Abdurrahman Wahid. Yohyakarta: LKIS Group, 2003.

http://www.gusdurian.net/id/9-Nilai-Utama-Gus-Dur/

http://www.gusdurian.net/id/article/headline/Sketsa-Nilai-danPemikiran-Gus-Dur/

Khalikin, Ahsanul dan Zirwansyah, Pandangan Pemuka Agama Tentang Ekslusivisme Beragama di Indonesia. Jakarta: Puslitbang Kehidupan Keagamaan Badan Litbang dan Diklat Kementerian Agama RI, 2013.

Mustajab, Ali, Kebijakan Politik Gus Dur Terhadap China Tionghoa di Indonesi. In Right, Jurnal Agama dan Hak Azazi Manusia, 2015.

Santalia, Indo, K.H Abdurrahman Wahid: Agama dan Negara, Pluralisme, Demokratisasi, dan Pribumisasi. Jurnal Al-Adyaan, Volume 1, nomor 2, Desember 2015.

Suseno, Franz Magnis, Gus Dur: Bangsa Mana di Dunia Mempunyai Presiden Seperti Kita! dalam Gila Gus Dur. Yogyakarta: LKiS, 2010.

Suyanto, dkk., Pengantar Psikologi Sosial. Surabaya: Pusat Penerbitan dan Percetakan Unair (AUP), 2012.

Wahid, Abdurrahman, Islamku Islam Anda dan Islam Kita. Jakarta, The Wahid Institute, 2006.

Wahid, Abdurrahman, Pendidikan Islam Harus Beragam, dimuat di koran Kedaulatan Rakyat pada 21 Desember 2002.

Yusup, Muhammad, "Eksklusivisme Beragama Jaringan Sekolah Islam Terpadu (JSIT) Yogyakarta", Jurnal Reigi vol. 13, No. 1, 2017 